\title{
Metallosphaera cuprina sp. nov., an acidothermophilic, metal-mobilizing archaeon
}

Correspondence
Cheng-Ying Jiang
jiangcy@sun.im.ac.cn

Extremely acidothermophilic Archaea are thought to be important micro-organisms in the evolutionary history of Earth. They have been found in acidic hot springs, water holes and mud holes that contain elemental sulfur and soils within continental solfataric fields (Brierley \& Brierley, 1973; de Rosa et al., 1975). Representatives of the genera Sulfolobus (Brock et al., 1972; Zillig et al., 1980), Acidianus (Segerer et al., 1986) and Metallosphaera (Takayanagi et al., 1996) have been isolated from a large number of these habitats (Huber \& Prangishvili, 2006). The genus Metallosphaera was first proposed by Huber et al. (1989) based on the physiological and DNA-DNA relatedness of metal-mobilizing strains isolated from a solfataric field. The type species of the genus is Metallosphaera sedula. Currently, the genus Metallosphaera contains three species

†These authors contributed equally to this work.

The GenBank/EMBL/DDBJ accession number for the 16S rRNA gene sequence of strain $\mathrm{Ar}-4^{\top}$ is FN796482.

Two supplementary figures are available with the online version of this paper. with validly published names (Huber et al., 1989; Fuchs et al., 1995; Kurosawa et al., 2003). Members of this genus grow aerobically at low $\mathrm{pH}$ values and high temperatures in the presence of elemental sulfur. In this paper, a novel species of the genus Metallosphaera is described that was isolated from the muddy water of a sulfuric hot spring in Yunnan province, China.

Muddy water samples were collected from the edge of the hot springs (temperature and $\mathrm{pH}$ ranges were $55-80{ }^{\circ} \mathrm{C}$ and $4.5-$ 5.5 , respectively) of Tengchong county ( $\mathrm{N} 24^{\circ} 38^{\prime}-25^{\circ} 52^{\prime}$, E $98^{\circ} 05^{\prime}-98^{\circ} 46^{\prime}$ ), Yunnan province, China. Samples were transferred to the laboratory within 3 days without temperature control and were processed immediately. Enrichment of acidothermophilic sulfur-oxidizers was performed in $250 \mathrm{ml}$ Erlenmeyer flasks with $100 \mathrm{ml}$ basal salt medium (BSM) (Chen et al., 2007), which was modified by the addition of $1 \mathrm{ml}$ trace element solution (containing per litre distilled water: $1.1 \mathrm{~g} \mathrm{FeCl}_{3} .6 \mathrm{H}_{2} \mathrm{O}, 0.05 \mathrm{~g} \mathrm{CuSO}_{4} \cdot 5 \mathrm{H}_{2} \mathrm{O}$, $0.2 \mathrm{~g} \mathrm{H}_{3} \mathrm{BO}_{3}, 0.2 \mathrm{~g} \mathrm{MnSO}_{4} . \mathrm{H}_{2} \mathrm{O}, 0.08 \mathrm{~g} \mathrm{Na}_{2} \mathrm{MoO}_{4} \cdot 2 \mathrm{H}_{2} \mathrm{O}$, $0.06 \mathrm{~g} \mathrm{CoCl}_{2} .6 \mathrm{H}_{2} \mathrm{O}$ and $\left.0.09 \mathrm{~g} \mathrm{ZnSO}_{4} .7 \mathrm{H}_{2} \mathrm{O}\right)$. The final $\mathrm{pH}$ was adjusted to 2.5 with $5 \mathrm{~mol} \mathrm{H}_{2} \mathrm{SO}_{4} \mathrm{l}^{-1}$. Elemental sulfur 
$\left(5 \mathrm{~g} \mathrm{l}^{-1}\right)$, sterilized by steaming for $3 \mathrm{~h}$ on three consecutive days, was added for chemolithoautotrophic culture. Cultures were incubated at $65{ }^{\circ} \mathrm{C}$ for 6 days. After three enrichment steps, the culture was serially diluted (10-fold) in tubes containing $9 \mathrm{ml}$ BSM. Samples of $0.2 \mathrm{ml}$ were spread on BSM Gelrite $(0.7 \%$, Difco) plates with potassium tetrathionate as the energy source and the plates were incubated at $65{ }^{\circ} \mathrm{C}$. Picked colonies were repeatedly streaked on plates for further purification. The method of Brock et al. (1972) was used to prepare the Gelrite plates. The purity of the clones was checked by $16 \mathrm{~S}$ rRNA gene sequence analysis and morphological observations performed using a phase-contrast microscope (Axiostar plus, Zeiss).

The growth temperature of the novel strain was examined from $50{ }^{\circ} \mathrm{C}$ to $80{ }^{\circ} \mathrm{C}$ (with intervals of $5{ }^{\circ} \mathrm{C}$ ) in BSM broth to which $2 \mathrm{~g}$ yeast extract $\mathrm{l}^{-1}$ was added instead of sulfur, at $\mathrm{pH}$ 2.5. For determination of the optimum $\mathrm{pH}$, strain Ar $-4^{\mathrm{T}}$ was cultured in the same medium at $65{ }^{\circ} \mathrm{C}$. The $\mathrm{pH}$ of the media (from pH 0 to 9.0, at intervals of $0.5 \mathrm{pH}$ units) was adjusted with $5 \mathrm{~mol} \mathrm{H}_{2} \mathrm{SO}_{4} \mathrm{l}^{-1}$ or $5 \mathrm{~mol} \mathrm{NaOH}$ $1^{-1}$. Cell growth was determined by measuring the increase of optical density at $520 \mathrm{~nm}\left(\mathrm{OD}_{520}\right)$.

Cell morphology and flagella were examined by scanning electron microscopy (Quanta 200; FEI) and transmission electron microscopy (H600; Hitachi). Gram-staining was determined according to the method described by Gerhardt et al. (1994). Carbon source utilization and other biochemical characterization tests were performed with modified Allen medium (Allen, 1959; Brock et al., 1972) as described previously (Huber et al., 1989; Fuchs et al., 1995; Takayanagi et al., 1996; Dong \& Cai, 2001). Growth of strain $\mathrm{Ar}-4^{\mathrm{T}}$ under anaerobic conditions was tested by using $\mathrm{H}_{2}$ as an electron donor and elemental sulfur as a terminal electron acceptor. To examine chemolithoautotrophic growth, the novel isolate was cultivated in Allen medium modified by the addition of $\left(1^{-1}\right): 5 \mathrm{~g}$ elemental sulfur, $5 \mathrm{mmol} \mathrm{K}_{2} \mathrm{~S}_{4} \mathrm{O}_{6}, 10 \mathrm{mmol}$ $\mathrm{Na}_{2} \mathrm{~S}_{2} \mathrm{O}_{3}, 13.9 \mathrm{~g} \mathrm{FeSO}_{4} .7 \mathrm{H}_{2} \mathrm{O}, 5 \mathrm{~g}$ pyrite or $5 \mathrm{~g}$ chalcopyrite. $\mathrm{K}_{2} \mathrm{~S}_{4} \mathrm{O}_{6}, \mathrm{Na}_{2} \mathrm{~S}_{2} \mathrm{O}_{3}$ or $\mathrm{FeSO}_{4}$ were added as filtersterilized solutions to the sterilized basal Allen medium $\left(121{ }^{\circ} \mathrm{C}\right.$ for $\left.20 \mathrm{~min}\right)$. Growth on sulfur, $\mathrm{K}_{2} \mathrm{~S}_{4} \mathrm{O}_{6}$ or $\mathrm{Na}_{2} \mathrm{~S}_{2} \mathrm{O}_{3}$ was determined by examination with phasecontrast microscopy and by a decrease in the $\mathrm{pH}$ of the medium. Utilization of $\mathrm{FeSO}_{4}$, pyrite or chalcopyrite at $\mathrm{pH} 2.0$ was monitored by phase-contrast microscopy and by the detection of increased concentrations of $\mathrm{Fe}^{2+}$ and $\mathrm{Cu}^{2+}$ in the supernatant of centrifuged cultures, determined spectrophotometrically according to Tamura et al. (1974) and Bixian (2006).

For analysis of lipid patterns, strain Ar- $4^{\mathrm{T}}$, M. sedula DSM $5348^{\mathrm{T}}$ and Sulfolobus acidocaldarius NBRC $15157^{\mathrm{T}}$ [obtained from NITE Biological Research Center (NBRC)] were grown in modified Allen broth at $65{ }^{\circ} \mathrm{C}$ (strain $\mathrm{Ar}-4^{\mathrm{T}}$ and $M$. sedula) or $70{ }^{\circ} \mathrm{C}$ (S. acidocaldarius). Total cellular lipids were extracted from stationary-phase cells (approximately $2 \mathrm{~g}$ wet weight) with $4.0 \mathrm{ml}$ chloroform/methanol/water
$(1: 2: 0.5, \mathrm{v} / \mathrm{v})$ with sonication and centrifugation. The extraction procedure was repeated three times and supernatants were combined and dried using a rotary evaporator at $40{ }^{\circ} \mathrm{C}$. Residual lipids were dissolved by adding $1 \mathrm{ml}$ chloroform/methanol $(2: 1, \mathrm{v} / \mathrm{v})$ and $0.1 \mathrm{ml}$ water with thorough mixing. Methanol was then added to the mixture until the solution was clear. The mixture contained crude total lipid. Cyclic tetraether core lipids were prepared by acid methanolysis of total cellular lipids as described by Sugai et al. (1995), and were applied to TLC plates (Merck silica gel 60 HPTLC; Merck) that were activated at $110{ }^{\circ} \mathrm{C}$ for $2 \mathrm{~h}$ before use. The cyclic tetraether core lipids were separated by chromatography with two ascending runs as described by Itoh et al. (2001). The spots on the TLC plates were detected by spraying the plate with sulfuric acid/ethanol $(1: 1 \mathrm{v} / \mathrm{v})$ followed by heating at $120{ }^{\circ} \mathrm{C}$ for $5-10 \mathrm{~min}$.

The genomic DNA of strain $\operatorname{Ar}-4^{\mathrm{T}}$ and other recognized species of the genus Metallosphaera was prepared as described previously (Marmur, 1961). The DNA G+C content was determined by the thermal denaturation method (Marmur \& Doty, 1962) using DNA from Escherichia coli $\mathrm{K}-12$ as a standard. DNA-DNA hybridization experiments were performed by the thermal denaturation and renaturation method as described by De Ley et al. (1970) and modified by Huß et al. (1983).

The nearly complete $16 \mathrm{~S}$ rRNA gene of strain $\mathrm{Ar}-4^{\mathrm{T}}$ was amplified with the primers 8aF $\left(5^{\prime}\right.$-TCYGGTTGATCCTGCC- $3^{\prime}$ ) and 1512uR (5'-ACGGHTACCTTGTTACGACTT- $3^{\prime}$ ) and was sequenced. Alignments of $16 \mathrm{~S}$ rRNA gene sequences were performed with the CLUSTAL_X program, version 1.64b (Thompson et al., 1997), and positions with insertions or deletions were excluded during calculations. A neighbour-joining phylogenetic tree was constructed using MEGA 3.1 (Saitou \& Nei, 1987; Kumar et al., 2004) based on evolutionary distances that were calculated with the Kimura two-parameter model (Kimura, 1980).

Colonies of strain $\mathrm{Ar}-4^{\mathrm{T}}$ on modified Allen plates supplemented with potassium tetrathionate were semitransparent, smooth, rounded and convex with a diameter of $0.2-0.3 \mathrm{~mm}$. Colonies on modified Allen plates supplemented with $\mathrm{FeSO}_{4}$ and $0.2 \mathrm{~g}$ yeast extract $\mathrm{l}^{-1}$ were brown, circular, flat and entire with a diameter of $0.7-$ $0.8 \mathrm{~mm}$. Cells of strain Ar- $4^{\mathrm{T}}$ were Gram-staining-negative, irregular cocci (lobed) with diameters of $0.9-1.0 \mu \mathrm{m}$ (Fig. 1). Active motility was observed using a light microscope; long and curved flagella were observed with a transmission electron microscope (Fig. 1).

Strain $\mathrm{Ar}-4^{\mathrm{T}}$ was strictly aerobic, grew at between 55 and $75{ }^{\circ} \mathrm{C}$ and over a $\mathrm{pH}$ range of $\mathrm{pH} 2.5$ to 5.5 . The optimal $\mathrm{pH}$ and temperature for growth were $\mathrm{pH} 3.5$ and $65^{\circ} \mathrm{C}$. The initial $\mathrm{pH}$ range for growth on sulfur was between 1.0 and 6.0 ; the optimum cell density of approximately $8.0 \times 10^{7}$ cells $\mathrm{ml}^{-1}$ occurred at $\mathrm{pH}$ 3.5. The final $\mathrm{pH}$ of the medium decreased to approximately $\mathrm{pH} 0.98-2.15$. Thus, the novel strain was apparently an extreme acidothermophile. 

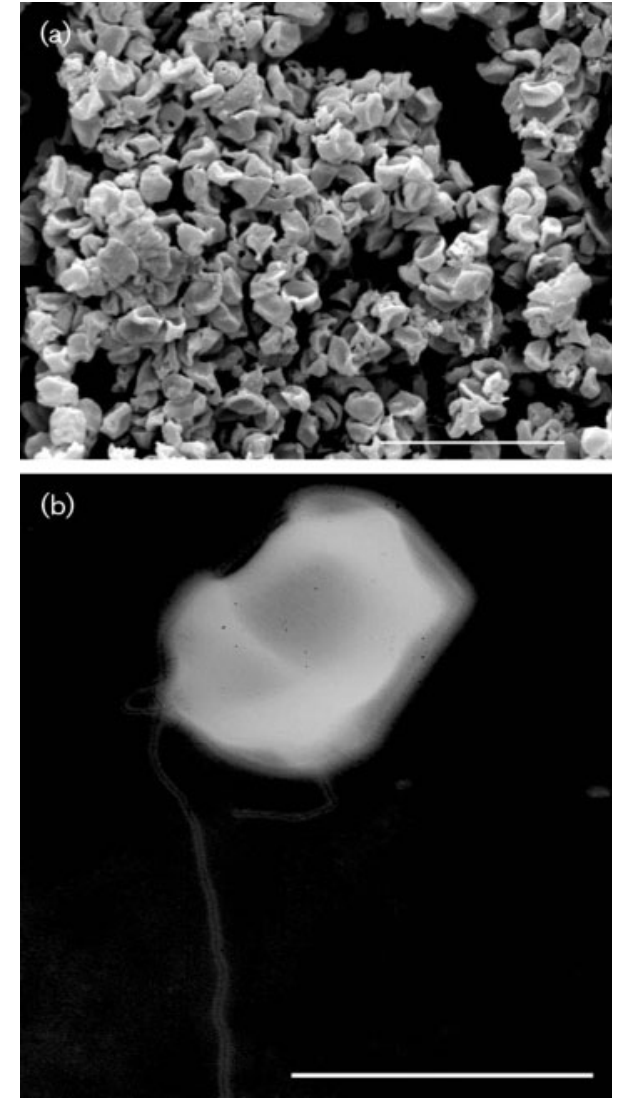

Fig. 1. Scanning (a) and transmission (b) electron micrographs showing the morphology of cells and flagella of strain $\mathrm{Ar}-4^{\top}$. Bars, $5 \mu \mathrm{m}$ (a) and $1 \mu \mathrm{m}$ (b).

Strain $\mathrm{Ar}-4^{\mathrm{T}}$ grew chemolithoautotrophically on elemental sulfur, $\mathrm{K}_{2} \mathrm{~S}_{4} \mathrm{O}_{6}$ and $\mathrm{FeSO}_{4}$. Pyrite and chalcopyrite were oxidized and supported the growth of the strain. On chalcopyrite, strain $\mathrm{Ar}-4^{\mathrm{T}}$ mobilized around $10.6 \%$ of the total copper within 12 days (maximum cell densities of approximately $3.0 \times 10^{7}$ cells $\mathrm{ml}^{-1}$ ). Yeast extract stimulated the growth of strain $\operatorname{Ar}-4^{\mathrm{T}}$. Under anaerobic conditions and in the presence of hydrogen and elemental sulfur, neither growth nor $\mathrm{H}_{2} \mathrm{~S}$ production occurred. Organotrophic growth occurred on yeast extract, beef extract, peptone, tryptone, Casamino acids, L-tryptophan, $\mathrm{L}$-arabinose, $\mathrm{D}$-xylose and $\mathrm{D}$-glucose. Strain $\mathrm{Ar}-4^{\mathrm{T}}$ grew weakly in the presence of $1.0 \% \mathrm{~L}$-aspartic acid, L-glutamic acid, L-alanine, sucrose and raffinose; no growth occurred on D-fructose, D-galactose, D-mannose, D-rhamnose, lactose, maltose or other amino acids. Based on these phenotypic studies, strain $\operatorname{Ar}-4^{\mathrm{T}}$ showed a range of characteristics that were different from those of recognized species of the genus Metallosphaera (Table 1). The optimal growth temperature of strain $\mathrm{Ar}-4^{\mathrm{T}}$ was lower and the optimal $\mathrm{pH}$ for growth was higher than for other species of the genus Metallosphaera. Strain $\mathrm{Ar}-4^{\mathrm{T}}$ was motile by means of flagella, but flagella have not been reported for $M$. hakonensis DSM $7519^{\mathrm{T}}$ or M. sedula DSM $5348^{\mathrm{T}}$. Other differences included the ability to assimilate various carbon sources and to oxidize inorganic ferrous iron or sulfuric compounds. In contrast to M. hakonensis, strain $\mathrm{Ar}-4^{\mathrm{T}}$ grew well on elemental sulfur but weakly on pyrite (or FeS) and could not utilize $\mathrm{H}_{2} \mathrm{~S}$ as a sulfur source. In addition, strain $\mathrm{Ar}-4^{\mathrm{T}}$ utilized more types of sugar (such as Darabinose, D-xylose and D-glucose) and amino acids than the other three recognized species of the genus Metallosphaera (see Table 1), but used fewer kinds of organic carbon resources than most of the members of the genus Sulfolobus. The detailed physiological and biochemical characteristics of strain $\operatorname{Ar}-4^{\mathrm{T}}$ and properties that distinguish it from its close relatives are given in the species description and shown in Table 1.

The analysis of the core lipids of strain $\mathrm{Ar}-4^{\mathrm{T}}$ and type strains of M. sedula and S. acidocaldarius by TLC revealed that these strains produced identical core lipids (see Supplementary Fig. S1 in IJSEM Online) that were previously identified as calditoglycerocaldarchaeol (CGTE) (Nishihara et al., 1987) and caldarchaeol (DGTE) (Sugai et al., 1995). The DNA $\mathrm{G}+\mathrm{C}$ content of strain $\mathrm{Ar}-4^{\mathrm{T}}$ (40.2 mol\%), was slightly lower than those of M. hakonensis DSM $7519^{\mathrm{T}}$, M. sedula DSM $5348^{\mathrm{T}}$ and $M$. prunae DSM $10039^{\mathrm{T}}$, which were $40.5 \mathrm{~mol} \%, 44.4 \mathrm{~mol} \%$ and $44.4 \mathrm{~mol} \%$, respectively, as detected by the thermal denaturation method used in this study. The values were lower than those detected by the HPLC method as reported by Kurosawa et al. (2003) (shown in Table 1).

$16 \mathrm{~S}$ rRNA gene sequence analysis revealed that strain $\mathrm{Ar}-4^{\mathrm{T}}$ was phylogenetically related to members of the genus Metallosphaera (sequence similarity range of 96.8-97.7\%), with the highest similarity (97.7\%) to M. hakonensis, and less than $90 \%$ and $88 \%$ similarities to other recognized species of the genera Acidianus and Sulfolobus, respectively. The neighbour-joining tree (Fig. 2) showed that strain Ar $-4^{\mathrm{T}}$ belonged to the family Sulfolobaceae and clustered with species of the genus Metallosphaera. This cluster of members of the genus Metallosphaera was also topologically supported by the minimal evolution and maximumparsimony trees (see Supplementary Fig. S2).

The DNA-DNA hybridization values for strain $\mathrm{Ar}-4^{\mathrm{T}}$ with M. hakonensis DSM $7519^{\mathrm{T}}$, M. sedula DSM $5348^{\mathrm{T}}$ and $M$. prunae DSM $10039^{\mathrm{T}}$ were $47.5 \%, 30.8 \%$ and $29.1 \%$, respectively, which were below the threshold value $(70 \%)$ recommended for the delineation of genomic species (Wayne et al., 1987). This indicated that strain $\mathrm{Ar}-4^{\mathrm{T}}$ represents a distinct genospecies of the genus Metallosphaera.

Based on these phenotypic and phylogenetic studies, it is concluded that strain $\mathrm{Ar}-4^{\mathrm{T}}$ represents a novel species of the genus Metallosphaera, for which the name Metallosphaera cuprina sp. nov., is proposed.

\section{Description of Metallosphaera cuprina sp. nov.}

Metallosphaera cuprina (cu'pri.na. L. n. cuprum copper; L. suff. -inus - $a$-um suffix used with the sense of belonging to; 
Table 1. Morphological, physiological and biophysical properties of strain Ar-4 ${ }^{\top}$ and some related strains of the family Sulfolobaceae

Strains: 1, M. cuprina Ar-4 $4^{\mathrm{T}}$; 2, M. hakonensis DSM $7519^{\mathrm{T}}$ (data from Takayanagi et al., 1996); 3, M. sedula DSM 5348 ${ }^{\mathrm{T}}$ (Huber et al., 1989); 4, M. prunae DSM 10039 ${ }^{\mathrm{T}}$ (Fuchs et al., 1995); 5, S. acidocaldarius ATCC 33909 ${ }^{\mathrm{T}}$ (Takayanagi et al., 1996; Brock et al., 1972; Zillig et al. 1980); 6, S. solfataricus DSM 1616 ${ }^{\mathrm{T}}$ (Takayanagi et al., 1996; Brock et al., 1972; Zillig et al., 1980); 7, A. infernus DSM 3191 ${ }^{\mathrm{T}}$ (Segerer et al., 1986; He et al., 2004; Yoshida et al., 2006); 8, A. brierleyi DSM 165 ${ }^{\mathrm{T}}$ (Segerer et al., 1986; He et al., 2004; Yoshida et al., 2006). +, Positive; -, negative; NA, not available; W, weakly positive. Data for taxa 1-3 for the sugar, amino acid and organic substrate experiments were obtained as described by Takayanagi et al. (1996). The amount of growth was expressed as the ratio (R) of $A_{520}$ after 6 days of incubation to $A_{520}$ before incubation, as follows:,$- R=1$; \pm , $1 \leqslant \mathrm{R} \leqslant 2 ;+, 2 \leqslant \mathrm{R} \leqslant 10 ;++, \mathrm{R} \geqslant 10$. The tests on the other three species of the genus Metallosphaera were run in parallel with strain Ar-4 $4^{\mathrm{T}}$. When the results from this study are different from previously reported data or when no other data are available, the results from this study are given in parentheses. Strain Ar- $4^{\mathrm{T}}$ did not utilize L-cysteine, L-glutamine, L-lysine, L-methionine, L-tyrosine, L-valine or L-serine. Other amino acids that were utilized weakly included L-threonine, L-arginine, L-asparagine, L-glycine, L-isoleucine, L-leucine, L-phenylalanine and L-proline. All species were Gram-staining-negative and utilized elemental sulfur.

\begin{tabular}{|c|c|c|c|c|c|c|c|c|}
\hline Characteristic & 1 & 2 & 3 & 4 & 5 & 6 & 7 & 8 \\
\hline Cell shape s $^{*}$ & IC & $\mathrm{L}$ & IC & $\mathrm{L}$ & $\mathrm{L}$ & $\mathrm{L}$ & IC & IC \\
\hline Cell diameter $(\mu \mathrm{m})$ & $0.9-1.0$ & $0.9-1.1$ & 1.0 & 1.0 & $0.8-1.0$ & $0.8-2.0$ & $0.5-1.5$ & $1-1.5$ \\
\hline Flagella & + & - & NA & + & - & - & NA & NA \\
\hline Motility & + & - & + & + & - & - & - & - \\
\hline Growth temperature range $\left({ }^{\circ} \mathrm{C}\right)$ & $55-75$ & $50-80$ & $50-80$ & $55-80$ & $55-85$ & $55-85$ & $65-96$ & $45-75$ \\
\hline Optimum growth temperature & 65 & 70 & 75 & 75 & 70 & 70 & 90 & 70 \\
\hline Growth $\mathrm{pH}$ range & $2.5-5.5$ & $1.0-4.0$ & $1.0-4.5$ & $1.0-4.5$ & $2.0-4.0$ & $3.5-5.0$ & $1.0-5.5$ & $1.0-6.0$ \\
\hline Optimum $\mathrm{pH}$ & 3.5 & 3.0 & 2.5 & NA & 2.5 & 4.5 & 2.0 & $1.5-2.0$ \\
\hline DNA G + C content $(\mathrm{mol} \%)$ & $40.2 \pm 0.5 \dagger$ & $38.4 \pm 1.5 \dagger 46.2 \ddagger$ & 45 & 46.0 & $38.2 \pm 1.5 \dagger$ & 36 & 31 & 31 \\
\hline \multicolumn{9}{|l|}{ Utilization of sulfur sources } \\
\hline Tetrathionate & + & + & + & - & + & + & NA & $\mathrm{NA}$ \\
\hline $\mathrm{H}_{2} \mathrm{~S}$ & - & + & NA & NA & + & + & NA & NA \\
\hline Pyrite (or FeS) & + & ++ & + & + & ++ & + & NA & NA \\
\hline Anaerobic with $\mathrm{H}_{2}$ and $\mathrm{S}$ & - & - & - & - & - & - & + & + \\
\hline \multicolumn{9}{|l|}{ Utilization of sugars } \\
\hline L-Arabinose & + & - & - & - & \pm & \pm & - & - \\
\hline D-Ribose & - & - & - & - & - & \pm & - & - \\
\hline D-Xylose & + & - & - & - & - & \pm & - & - \\
\hline D-Fructose & - & - & - & - & \pm & \pm & - & - \\
\hline D-Galactose & - & - & - & - & - & ++ & - & - \\
\hline D-Glucose & + & - & - & - & + & ++ & - & - \\
\hline D-Mannose & - & - & $-( \pm)$ & $-( \pm)$ & ++ & ++ & - & - \\
\hline Lactose & - & - & - & - & - & ++ & - & - \\
\hline Maltose & - & $\pm(+)$ & - & - & + & ++ & - & - \\
\hline Sucrose & \pm & - & - & - & ++ & + & - & - \\
\hline Raffinose & \pm & - & - & - & ++ & + & - & - \\
\hline \multicolumn{9}{|l|}{ Utilization of amino acids } \\
\hline L-Aspartic acid & \pm & - & $( \pm)$ & $(+)$ & \pm & \pm & - & - \\
\hline L-Glutamic acid & \pm & $\pm(+)$ & $( \pm)$ & $(+)$ & + & $\mathrm{w}$ & - & - \\
\hline L-Tryptophan & + & \pm & $(+)$ & $( \pm)$ & + & - & - & - \\
\hline L-Alanine & \pm & - & $(+)$ & $(+)$ & NA & NA & - & - \\
\hline \multicolumn{9}{|l|}{ Utilization of organic substrate } \\
\hline Yeast extract & + & ++ & + & + & ++ & ++ & - & + \\
\hline Beef extract & + & $(+)$ & + & + & NA & $\mathrm{NA}$ & - & + \\
\hline Peptone & ++ & $(+)$ & + & + & + & NA & - & + \\
\hline Tryptone & + & $( \pm)$ & $+(++)$ & $(+)$ & + & NA & - & + \\
\hline Casamino acids & ++ & $(+)$ & $+(++)$ & $-(+)$ & + & $\mathrm{NA}$ & - & + \\
\hline
\end{tabular}

${ }^{\star}$ IC, irregular cocci; L, lobed.

$\dagger$ Values given are means with standard deviations from three replications.

$\ddagger$ The value of $38.4 \mathrm{~mol} \%$ was determined from the $\mathrm{CsCl}$ isopycnic centrifugation method (Takayanagi et al., 1996), the value of $46.2 \mathrm{~mol} \%$ was determined by HPLC (Kurosawa et al., 2003). 


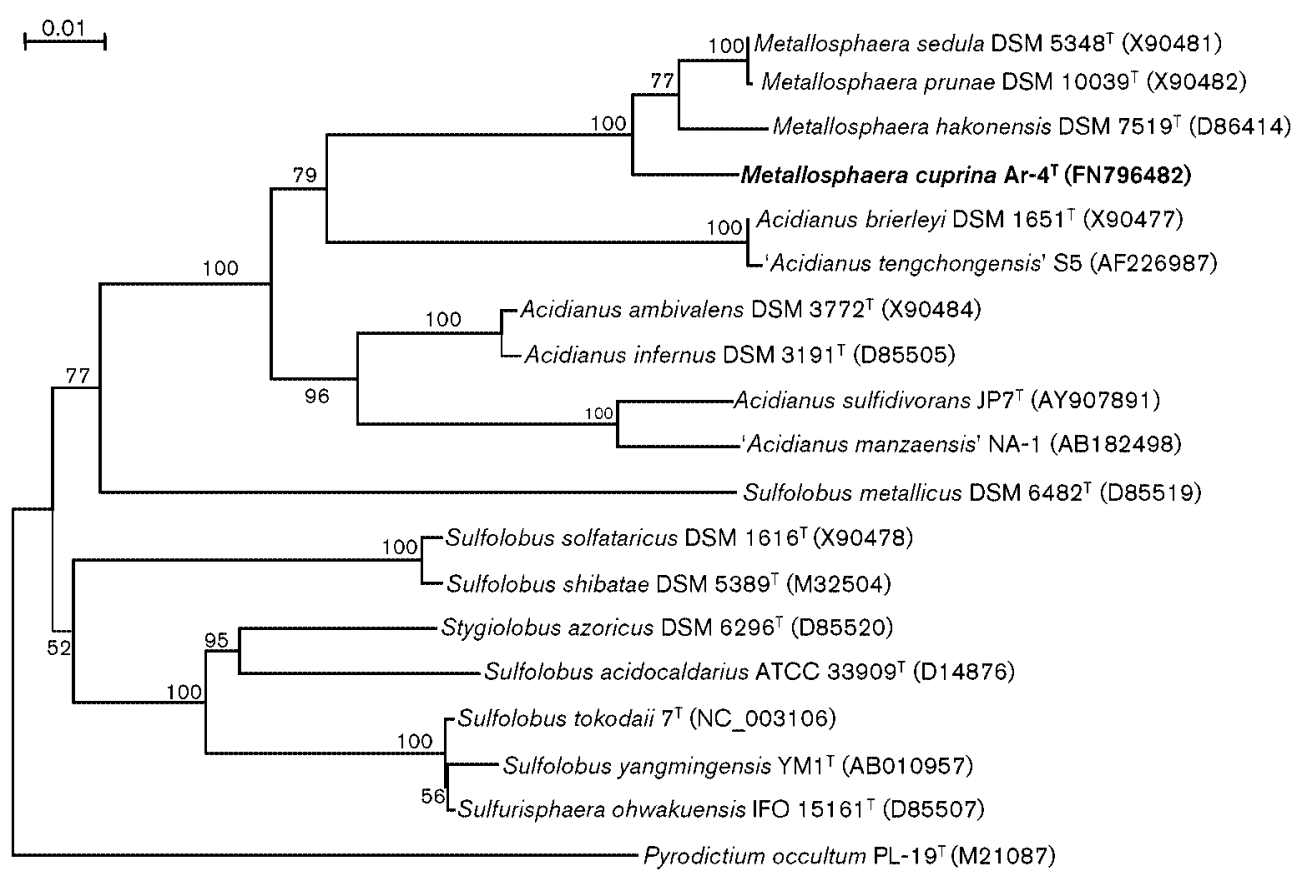

Fig. 2. Phylogenetic tree constructed with the neighbour-joining method according to $16 \mathrm{~S}$ rRNA gene sequence evolutionary distances among strain $\mathrm{Ar}-4^{\top}$ and other members of the family Sulfolobaceae. Pyrodictium occultum PL-19 ${ }^{\top}$ (M21087) was used as the outgroup. GenBank accession numbers are given in parentheses. Numbers represent confidence levels (values $>50 \%$ are shown) from 1000 replicate bootstrap samplings. Bar, 0.01 substitutions per nucleotide position.

N.L. fem. adj. cuprina belonging to copper, describing its ability to extract copper ions from ores).

Cells are irregular cocci $(0.9-1.0 \mu \mathrm{m})$, Gram-stainingnegative and motile by means of flagella. Clones on modified Allen plates supplemented with potassium tetrathionate are semi-transparent, smooth, rounded and convex with a diameter of $0.2-0.3 \mathrm{~mm}$. Clones on modified Allen plates supplemented with $\mathrm{FeSO}_{4}$ are brown, circular and flat. Growth occurs in extremely acidothermophilic conditions with growth temperatures from 55 to $75{ }^{\circ} \mathrm{C}$ (optimum $65{ }^{\circ} \mathrm{C}$ ) and at $\mathrm{pH} 2.5$ to 5.5 (optimum $\mathrm{pH}$ 3.5). Cells grow well in modified Allen medium containing $0-1 \%(\mathrm{w} / \mathrm{v}) \mathrm{NaCl}$ and growth is inhibited by $2 \%(\mathrm{w} / \mathrm{v}) \mathrm{NaCl}$. Aerobic, facultatively chemolithoautotrophic growth on elemental sulfur, $\mathrm{K}_{2} \mathrm{~S}_{4} \mathrm{O}_{6}, \mathrm{FeSO}_{4}$, pyrite (or FeS) and chalcopyrite. Chemolithoautotrophic growth is stimulated by yeast extract. Hydrogen sulfide is not produced when grown on elemental sulfur and hydrogen under anaerobic conditions. Organotrophic growth on yeast extract, beef extract, peptone, Casamino acids, Ltryptophan, D-arabinose, D-xylose and D-glucose; weak growth on sucrose, raffinose, L-aspartic acid, L-glutamic acid and L-alanine. The main cellular lipids are calditoglycerocaldarchaeol (CGTE) and caldarchaeol (DGTE). 16S rRNA gene sequence similarity between $M$. cuprina and $M$. hakonensis DSM $7519^{\mathrm{T}}$, M. sedula DSM $5348^{\mathrm{T}}$ and $M$. prunae DSM $10039^{\mathrm{T}}$ is $97.7 \%, 97.0 \%$ and $96.8 \%$, respectively.
The type strain, $\operatorname{Ar}-4^{\mathrm{T}}\left(=\mathrm{JCM} 15769^{\mathrm{T}}=\right.$ CGMCC $\left.1.7082^{\mathrm{T}}\right)$, was isolated from muddy water samples from a sulfuric hot spring of Tengchong county, Yunnan province, China. The DNA $\mathrm{G}+\mathrm{C}$ content of the type strain is $40.2 \mathrm{~mol} \%$.

\section{Acknowledgements}

This work was supported by a grant from the National Nature Science Foundation of China (30621005) and by a grant from the National Basic Research Program of China (2010CB630903).

\section{References}

Allen, M. B. (1959). Studies with Cyanidium caldarium, an anomalously pigmented chlorophyte. Arch Mikrobiol 32, 270277.

Bixian, J. (2006). The mensuration of the copper contents in the stannum based alloy with BCO Light intensity method. Heavy Cast Forg 1, 37-38.

Brierley, C. L. \& Brierley, J. A. (1973). A chemoautotrophic and thermophilic microorganism isolated from an acid hot spring. Can J Microbiol 19, 183-188.

Brock, T. D., Brock, K. M., Belly, R. T. \& Weiss, R. L. (1972). Sulfolobus: a new genus of sulfur-oxidizing bacteria living at low $\mathrm{pH}$ and high temperature. Arch Mikrobiol 84, 54-68.

Chen, Z. W., Liu, Y. Y., Wu, J. F., She, Q. X., Jiang, C. Y. \& Liu, S. J. (2007). Novel bacterial sulfur oxygenase reductases from bioreactors treating gold-bearing concentrates. Appl Microbiol Biotechnol 74, 688-698. 
De Ley, J., Cattoir, H. \& Reynaerts, A. (1970). The quantitative measurement of DNA hybridization from renaturation rates. Eur $J$ Biochem 12, 133-142.

de Rosa, M., Gambacorta, A. \& Bu'lock, J. D. (1975). Extremely thermophilic acidophilic bacteria convergent with Sulfolobus acidocaldarius. J Gen Microbiol 86, 156-164.

Dong, X. Z. \& Cai, M. Y. (2001). Determinative Manual for Routine Bacteriology (English translation). Beijing: Academic Press.

Fuchs, T., Huber, H., Teiner, K., Burggraf, K. \& Stetter, K. O. (1995). Metallosphaera prunae, sp. nov., a novel metal-mobilizing, thermoacidophilic archaeum, isolated from a uranium mine in Germany. Syst Appl Microbiol 18, 560-566.

Gerhardt, P., Murray, R. G. E., Wood, W. A. \& Krieg, N. R. (1994). Methods for General and Molecular Bacteriology. Washington, DC: American Society for Microbiology.

He, Z. G., Zhong, H. F. \& Li, Y. Q. (2004). Acidianus tengchongensis sp. nov., a new species of acidothermophilic archaeon isolated from an acidothermal spring. Curr Microbiol 48, 159-163.

Huber, H. \& Prangishvili, D. (2006). Sulfolobales. In The Prokaryotes, vol. 3, pp. 23-51. Edited by M. Dworkin, S. Falkow, E. Rosenberg, K. H. Schleifer \& E. Stackebrandt. Singapore: Springer.

Huber, G., Spinnler, C., Gambacorta, A. \& Stetter, K. O. (1989). Metallosphaera sedula gen. nov. and sp. nov. represents a new genus of aerobic, metal-mobilizing, thermoacidophilic archaebacteria. Syst Appl Microbiol 12, 38-47.

Huß, V. A. R., Festl, H. \& Schleifer, K. H. (1983). Studies on the spectrophotometric determination of DNA hybridization from renaturation rates. Syst Appl Microbiol 4, 184-192.

Itoh, Y. H., Kurosawa, N., Uda, I., Sugai, A., Tanoue, S., Itoh, T., Horiuchi, T. \& Itoh, T. (2001). Metallosphaera sedula TA-2, a calditoglycerocaldarchaeol deletion strain of a thermoacidophilic archaeon. Extremophiles 5, 241-245.

Kimura, M. (1980). A simple method for estimating evolutionary rates of base substitutions through comparative studies of nucleotide sequences. J Mol Evol 16, 111-120.

Kumar, S., Tamura, K. \& Nei, M. (2004). MEGA3: Integrated software for molecular evolutionary genetics analysis and sequence alignment. Brief Bioinform 5, 150-163.

Kurosawa, N., Itoh, Y. H. \& Itoh, T. (2003). Reclassification of Sulfolobus hakonensis Takayanagi et al. 1996 as Metallosphaera hakonensis comb. nov. based on phylogenetic evidence and DNA $\mathrm{G}+\mathrm{C}$ content. Int J Syst Evol Microbiol 53, 1607-1608.
Marmur, J. (1961). A procedure for the isolation of deoxyribonucleic acid from microorganisms. J Mol Biol 3, 208-218.

Marmur, J. \& Doty, P. (1962). Determination of the base composition of deoxyribonucleic acid from its thermal denaturation temperature. J Mol Biol 5, 109-118.

Nishihara, M., Morii, H. \& Koga, Y. (1987). Structure determination of a quartet of novel tetraether lipids from Methanobacterium thermoautotrophicum. J Biochem 101, 1007-1015.

Saitou, N. \& Nei, M. (1987). The neighbor-joining method: a new method for reconstructing phylogenetic trees. Mol Biol Evol 4, 406-425.

Segerer, A., Neuner, A., Kristjansson, J. K. \& Stetter, K. O. (1986). Acidianus infernus gen. nov., sp. nov., and Acidianus brierleyi comb. nov.: facultatively aerobic, extremely acidophilic thermophilic sulfur-metabolizing archaebacteria. Int J Syst Bacteriol 36, 559-564.

Sugai, A., Sakuma, R., Fukuda, I., Kurosawa, N., Itoh, Y. H., Kon, K., Ando, S. \& Itoh, T. (1995). The structure of the core polyol of the ether lipids from Sulfolobus acidocaldarius. Lipids 30, 339-344.

Takayanagi, S., Kawasaki, H., Sugimori, K., Yamada, T., Sugai, A., Ito, T., Yamasato, K. \& Shioda, M. (1996). Sulfolobus hakonensis sp. nov., a novel species of acidothermophilic archaeon. Int $J$ Syst Bacteriol 46, 377-382.

Tamura, H., Goto, K., Yotsuyanagi, T. \& Nagayama, M. (1974). Spectrophotometric determination of iron(II) with 1,10-phenanthroline in the presence of large amounts of iron(III). Talanta 21, 314-318.

Thompson, J. D., Gibson, T. J., Plewniak, F., Jeanmougin, F. \& Higgins, D. G. (1997). The CLUSTAL_X windows interface: flexible strategies for multiple sequence alignment aided by quality analysis tools. Nucleic Acids Res 25, 4876-4882.

Wayne, R. K., Nash, W. G. \& O'Brien, S. J. (1987). Chromosomal evolution of the Canidae. I. Species with high diploid numbers. Cytogenet Cell Genet 44, 123-133.

Yoshida, N., Nakasato, M., Ohmura, N., Ando, A., Saiki, H., Ishii, M. \& Igarashi, Y. (2006). Acidianus manzaensis sp. nov., a novel thermoacidophilic archaeon growing autotrophically by the oxidation of $\mathrm{H}_{2}$ with the reduction of $\mathrm{Fe}^{3+}$. Curr Microbiol 53, 406-411.

Zillig, W., Stetter, K. O., Wunderl, S., Schulz, W., Priess, H. \& Scholz, I. (1980). The Sulfolobus - "Caldariella" group: taxonomy on the bases of the structure of DNA-dependent RNA polymerases. Arch Microbiol $125,259-269$. 